\title{
ANALISIS PENGARUH RASIO KEUANGAN TERHADAP NILAI PERUSAHAAN
}

\author{
Ika Listyawati, Rosiana Ramadhan \\ Universitas Aki Semarang, Sekolah Tinggi Dharma Putra \\ Ika.listyawati@unaki.ac.id
}

Riwayat Artikel: dikirim Oktober 2018, diterima September 2018, diterbitkan September 2018

\section{ABSTRACT}

The purpose of this study was to test and analyze the influence of financial ratios on firm value carried out in the manufacturing companies listed on the Indonesia Stock Exchange period 2013 to 2017. The sampling in this study used a purposive sampling technique. Based on predetermined criteria, this study uses multiple linear regression analysis with the help of the SPSS program.

The results of multiple linear regression analysis were obtained by the regression equation $Y=\alpha+$ $\beta_{1} x_{1}+\beta_{2} x_{2}+\beta_{3} x_{3}+\varepsilon$. Based on the results of hypothesis testing, it was found that the variables of profitability and capital structure had a positive and significant effect on the value of the company, while the variable growth of the company was not significant towards firm value.

Keywords: company value, profitability, company growth and capital structure.

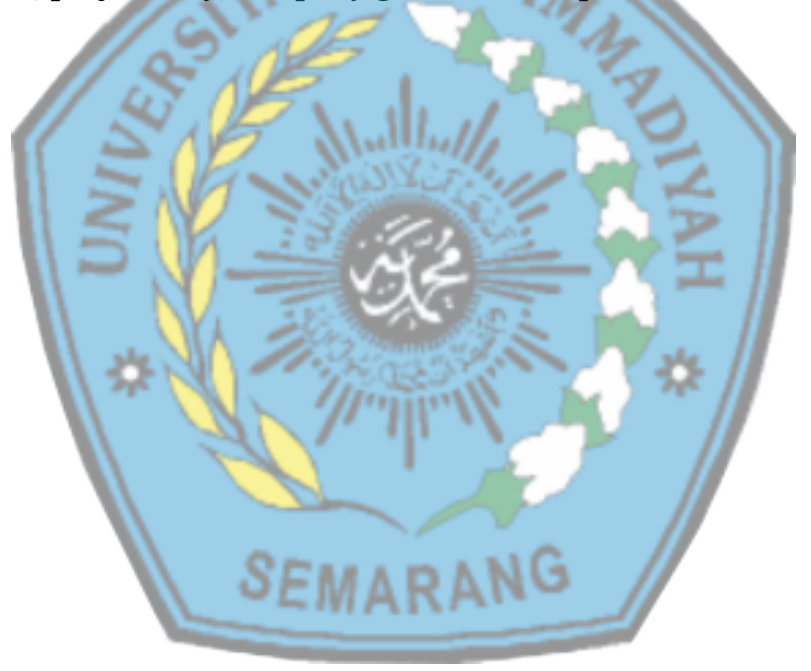




\section{PENDAHULUAN}

\section{Latar Belakang}

Salah satu tujuan utama didirikannya perusahaan adalah untuk mendapatkan laba. Didirikannya perusahaan dengan tujuan yang jelas, yang mana tujuan tersebut diantaranya adalah untuk menghasilkan laba, zmemakmurkan investor atau pemilik perusahaan, dan memaksimalkan nilai perusahaan yang dapat dilihat dari harga sahamnya. Ketiga tujuan perusahaan tersebut tidak banyak berbeda. Hanya saja penekanan yang ingin dicapai masing-masing perusahaan tidak sama satu dengan lainnya (Harjito dan Martono,2005).

Para investor dalam melakukan keputusan investasi di pasar modal memerlukan informasi tentang penilaian saham. Terdapat tiga (3) jenis penilaian yang berhubungan langsung dengan saham, antara lain nilai buku (book value), nilai pasar (market value), dan nilai intrinsik (intrinsic value). Nilai buku merupakan nilai sahammenurut pembukuan emiten. Nilai pasar merupakan pembukuan nilai saham di pasar saham dan nilai intrinsik yang merupakan nilai sebenarnya dari saham. Seorang investor perlu mengetahui dan memahami ketiga nilai tersebut sebagai tambahan informasi penting dalam pengambilan keputusan investasi saham karena dapat membantu seorang investor untuk mengetahui saham mana yang sedang bertumbuh dan murah. Salah satunya pendekatan dalam menentukan nilai intrinsik saham adalah price book value (PBV). PBV atau rasio harga per nilai buku merupakan hubungan antara harga pasar saham dengan nilai buku pada per lembar saham.

Nilai perusahaan adalah nilai pasar dari ekuitas perusahaan ditambah nilai pasar hutang. Dengan demikan, penambahan dari jumlah ekuitas perusahaan dengan hutang perusahaan dapat mencerminkan nilai perusahaan. Ada beberapa faktor dari penelitian terdahulu yang dapat mempengaruhi nilai perusahaan, antara lain: keputusan pendanaan, kebijakan deviden, keputusan investasi, pertumbuhan perusahaan, dan ukuran perusahaan.

\section{Tujuan}

1. Menganalisis pengaruh profitabilitas terhadap nilai perusahaan.

2. Menganalisis pengaruh pertumbuhan perusahaan terhadap nilai perusahaan.

3. Menganalisis pengaruh struktur modal terhadap nilai perusahaan.

4. Menganalisis pengaruh profitabilitas, pertumbuhan perusahaan, dan struktur modal secara bersama-sama terhadap nilai perusahaan.

\section{Landasan Teori}

17 Nilai perusahaan sangat penting karena nilai perusahaan yang tinggi akan diikuti juga oleh tingginya kemakmuran pemegang saham atau investor (Bringham Gapensi, 1996). Semakin tinggi tingkat harga saham - semakin tinggi pula nilai perusahaan. Nilai perusahaan yang tinggi dapat menarik keinginan para pemilik perusahaan dalam menanamkan sahamnya, karena dengan nilai perusahaan yang tinggi menunjukan kemakmuran pemegang saham juga tinggi pula. Kekayaan pemegang saham dan perusahaan dipresentasikan oleh harga pasar dari saham yang merupakan cerminan dari keputusan investasi, pendanaan (financing), dan manajemen aset. Nilai perusahaan merupakan nilai jual perusahaan atau nilai tumbuh bagi pemegang saham, nilai perusahaan dapat tercermin dari harga pasar sahamnya (Andri dan Hanung, 2007)

Nilai perusahaan menurut Rika dan Islahudin (2008) diartikan sebagai nilai pasar. Nilai perusahaan dapat memberikan kemakmuran pemegang saham atau investor secara maksimum apabila harga saham perusahaan meningkat. Semakin tinggi harga saham, maka makin tinggi kemakmuran seorang investor. Agar nilai perusahaan dapat

ANALISIS PENGARUH RASIO KEUANGAN....

Ika Listyawati, Rosiana Ramadhan

DOI 
meningkat sesuai yang diharapkan umumnya para pemodal menyerahkan pengelolaannya kepada para manajemen perusahaan. Manajemen perusahaan diposisikan sebagai manajer atau komisaris.

Nilai dari perusahaan bergantung tidak hanya pada kemampuan dalam menghasilkan arus kas, tetapi juga bergantung pada karateristik operasional dan keuangan perusahaan yang telah diambil alih. Beberapa variabel kuantitatif yang sering digunakan untuk memperkirakan nilai perusahaan antara lain:

1. Nilai Buku

Nilai buku per lembar saham (BVS) digunakan untuk mengukur suatu nilai shareholders equity atas setiap saham, dan besarnya nilai BVS dihitung dengan cara membagi total shareholders equity dengan jumlah saham yang beredar.

2. Nilai Appraisal

Nilai appraisal suatu perusahaan dapat diperoleh dari perusahaan appraisal independent.

3. Nilai Pasar Saham

Nilai pasar saham dinyatakan dalam kuotasi pasar modal adalah pendekatan lain untuk memperkirakan nilai bersih dari suatu bisnis.

4. Nilai "Chop-Shop"

Pendekatan "Chop-Shop" untuk mengevaluasi pertama kali diperkenalkan oleh Dean Lebaron dan Lawrence Speidell of Batterymarch Financial Management.

5. Nilai Arus Kas

Tiga jenis penilaian yang berhubungan dengan saham, yaitu nilai buku (book value), nilai pasar (market value) dan nilai intrinsik (intrinsic value).

Tujuan utama suatu perusahaan menurut theory of the firm adalah untuk memaksimumkan kekayaan perusahaan atau nilai perusahaan (value of the firm) (Salvatore, 2005). Memaksimalkan nilai perusahaan sangat penting bagi suatu perusahaan, karena dengan memaksimalkan nilai perusahaan sama artinya dengan memaksimalkan kemakmuran pemegang saham (Euis dan Taswan, 2002). Nilai perusahaan adalah persepsi investor terhadap tingkat keberhasilan perusahaan yang sering dikaitkan dengan harga saham. Tingkat harga saham yang tinggi membuat nilai perusahaan juga semakin tinggi.

\section{Teori Struktur Modal}

Teori struktur modal dimulai pada tahun 1958, Merton Mille menunjukkan dengan adanya sekumpulan asumsi yang sangat membatasi, bahwa nilai sebuah perusahaan tidak terpengaruh oleh struktur modalnya. Artinya, hasil yang diperoleh Merton Mille menunjukkan kondisi bagaimana sebuah perusahaan akan mendanai operasinya tidak akan ada artinya, sehingga struktur modal adalah suatu hal yang tidak relevan. Dengan menunjukkan suatu kondisi struktur modal yang tidak relevan, Merton Mille telah memberikan petunjuk mengenai hal apa saja yang dibutuhkan agar membuat struktur modal menjadi relevan yang selanjutnya akan mempengaruhi nilai perusahaan.

\section{Hipotesis}

1. H1 . Profitabilitas berpengaruh positif dan signifikan terhadap nilai

perusahaan

2. H2 : Pertumbuhan perusahaan berpengaruh positif dan tidak signifikan terhadap nilai perusahaan

3. H3 : Struktur Modal berpengaruh positif dan signifikan terhadap nilai Perusahaan

\section{METODE PENELITIAN}

Operasional variabel didefinisikan sebagai berikut:

1. Nilai Perusahaan (Y)

Nilai perusahaan diukur dengan Price Book Value (PBV) yang menunjukkan 
tingkat kemampuan perusahaan dalam menciptakan nilai relatif terhadap jumlah modal yang diinvestasikan. PBV yang tinggi mencerminkan harga saham yang tinggi dibandingkan nilai buku perlembar saham. Rasio ini dihitung dengan formula sebagai berikut (Robert, 1997):

$\mathrm{PBV}=\frac{P S}{B V S}$

Ps merupakan harga pasar saham dan BVS merupakan nilai buku per lembar saham (book value per share). BVS digunakan untuk mengukur nilai shareholders equity atas setiap saham, dan besarnya nilai BVS dihitung dengan cara membagi total shareholders equity dengan jumlah saham yang beredar.

2. Profitabilitas (X1)

Profitabilitas diukur dengan return on asset (ROA) yang artinya perbandingan antara laba bunga dan pajak (EBIT) dengan total aset yang dimiliki perusahaan.

$$
\mathrm{ROA}=\frac{\text { Net Income After Tax }}{\text { Average } \text { Total Asset }} \times 100 \%
$$

3. Pertumbuhan Perusahaan (X2)

Pertumbuhan perusahaan dapat diukur dengan menggunakan pertumbahan total aset. Pertumbuhan aset diperoleh dari selisih total aset yang dimiliki perusahaan pada periode sekarang dengan periode sebelumnya (Eli Safrida, 2008).

Perubahan Total

$\frac{\text { Total asset } t-\text { Total asset } t-1}{\text { Total asset } t-1} \times 100 \%$

\section{4. $\quad$ Struktur Modal (X3)}

Struktur modal diukur dengan debt to equity ratio (DER), adalah suatu upaya untuk memperlihatkan, dalam format lain,

$$
\begin{aligned}
& Y=\alpha+\beta_{1} X_{1}+\beta_{2} X_{2}+\beta_{3} X_{3}+\varepsilon \\
& \text { Keterangan: } \\
& Y \quad: \text { Nilai Perusahaan } \\
& X_{1}: \text { Profitabilitas } \\
& X_{2}: \text { Petumbuhan Perusahaan } \\
& X_{3}: \text { Struktur Modal } \\
& \alpha \quad: \text { Konstanta } \\
& \varepsilon \quad: \text { Standart Error }
\end{aligned}
$$

proporsi relatif dari klaim pemberi pinjaman terhadap hak kepemilikan , dan digunakan sebagai ukuran peranan hutang (Helfert, 1997).

DER $=\frac{\text { Total liabilities }}{\text { Total equity }} \times 100 \%$

Teknik pengambilan sampel menggunakan purposive sampling jenis judgement sampling yaitu sampel dipilih menggunakan pertimbangan tertentu disesuaikan dengan tujuan penelitian atau masalah penelitian yang dikembangkan (Ferdinand, 2006). Kriteria yang digunakan adalah :

1. Perusahaan manufaktur yang terdaftar di BEI tahun 2013 sampai akhir Desember 2017.

2. Perusahaan manufaktur yang menerbitkan laporan keuangan akhir tahun secara lengkap dari tahun 20132017 secara berturut-turut.

3. Perusahaan manufaktur yang menyajikan laporan keuangan dalam nominal rupiah.

4. Perusahaan manufaktur yang memperoleh laba selama periode penelitian.

\section{Teknik Analisis Data}

Data yang dikumpulkan dalam penelitian ini diolah dengan software SPSS dan diuji melalui analisis statistik deskriptif, pengujian regresi linier berganda, dan uji hipotesis.

\section{Uji Regresi Linier Berganda}

Model regresi berganda yang digunakan dalam penelitian ini disajikan dalam persamaan berikut: 


\section{HASIL DAN PEMBAHASAN}

Hasil Uji Analisis Statistik Deskriptif

\section{Descriptive Statistics}

\begin{tabular}{|l|l|l|l|l|l|}
\hline & $\mathrm{N}$ & Minimum & Maximum & Mean & Std. Deviation \\
\hline ROA & 125 & .78 & 71.51 & 14.0367 & 9.50281 \\
GROWTH & 125 & .65 & 85.36 & 17.8191 & 13.11871 \\
DER & 125 & .10 & 6.35 & .8375 & .79236 \\
PBV & 125 & .45 & 46.63 & 4.0858 & 6.92789 \\
Valid & $\mathrm{N}$ & 125 & & & \\
(listwise) & & & & & \\
\hline
\end{tabular}

Uji Asumsi Klasik

Pengujian normalitas data KolmogorovUji Normalitas

Smirnov (K-S) dengan membuat hipotesis

Hasil dari uji normalitas pada H0 : Data residual berdistribusi normal grafik histogram, normal probability plot, serta Kolmogorov-Smirnov Test. H1: Data residual tidak berdistribusi

\section{One-Sample Kolmogorov-Smirnov Test}

\begin{tabular}{|c|c|c|c|c|c|}
\hline & 6 & $\mathrm{ROA}$ & Growth & DER & PBV \\
\hline $\mathrm{N}$ & & $125 \div$ & 125 & 125 & 125 \\
\hline Normal Parameters ${ }^{\mathrm{a}, \mathrm{b}}$ & Mean & 14.0367 & 18.8191 & .8375 & 4.0858 \\
\hline & Std. Deviation & 9.50281 & 13.11871 & .79236 & 6.92789 \\
\hline Extreme & Absolute E & $.174^{3}$ & 154 & .176 & .320 \\
\hline Differences & Positive & .174 & .154 & .173 & .320 \\
\hline & Negative & -.105 & -.084 & -.176 & -.300 \\
\hline Kolmogorov-Smirnov Z & & 1.950 & 1.721 & 1.968 & 3.572 \\
\hline Asymp. Sig. (2-tailed) & & .001 & .005 & .020 & .000 \\
\hline
\end{tabular}

Besarnya nilai KolmogorovSmirnov untuk masing-masing variabel adalah 1.950 untuk Return On Assets, 1.721 untuk Growth, 1.968 untuk Debt To Equity Ratio,dan 3.572 untuk Price Book Value.

\section{Uji Autokorelasi}

Uji ini bertujuan untuk melihat model regresi linear ada korelasi antar kesalahan pengganggu pada periode $\mathrm{t}$ dengan kesalahan pada periode $\mathrm{t}-1$. Untuk uji Durbin Watson memiliki ketentuan sebagai berikut: 
Uji Statistik Durbin-Watson

\begin{tabular}{|l|l|}
\hline \multicolumn{1}{|c|}{ Durbin-Watson } & \multicolumn{1}{c|}{ Kesimpulan } \\
\hline$<1.10$ & Ada autokorelasi \\
\hline $1.11-1.54$ & Tanpa kesimpulan \\
\hline $1.55-2.46$ & Tidak ada autokorelasi \\
\hline $2.47-2.90$ & Tanpa kesimpulan \\
\hline$>2.90$ & Ada autokorelasi \\
\hline
\end{tabular}

Sumber : Algifari (2000)

\section{Hasil Uji Durbin-Watson}

Model Summary ${ }^{\mathrm{b}}$

\begin{tabular}{|l|l|l|l|l|l|}
\hline Model & $\mathrm{R}$ & $\mathrm{R}$ Square & $\begin{array}{l}\text { Adjusted } \\
\text { Square }\end{array}$ & $\begin{array}{l}\text { Std. Error of } \\
\text { the Estimate }\end{array}$ & $\begin{array}{l}\text { Durbin- } \\
\text { Watson }\end{array}$ \\
\hline 1 & $.664^{\mathrm{a}}$ & .441 & .427 & .63687 & 1.729 \\
\hline
\end{tabular}

Uji Multikolinearitas

Bertujuan untuk $S$ menguji apakah model regresi ditemukan adanya korelasi antar variabel bebasnya. Model regresi yang baik seharusnya tidak terjadi korelasi diantara variabel independennya. Untuk multikolinearitas dengan melihat VIF (Variance Inflation Factor). Multikolinearitas akan terjadi apabila tingkat VIF lebih besar dari 10 atau apabila nilai tolerance kurang dari 0,1 (Imam Ghozali, 2006). Hasil uji multikolinearitas:

\section{Coefficients $^{\mathrm{a}}$}

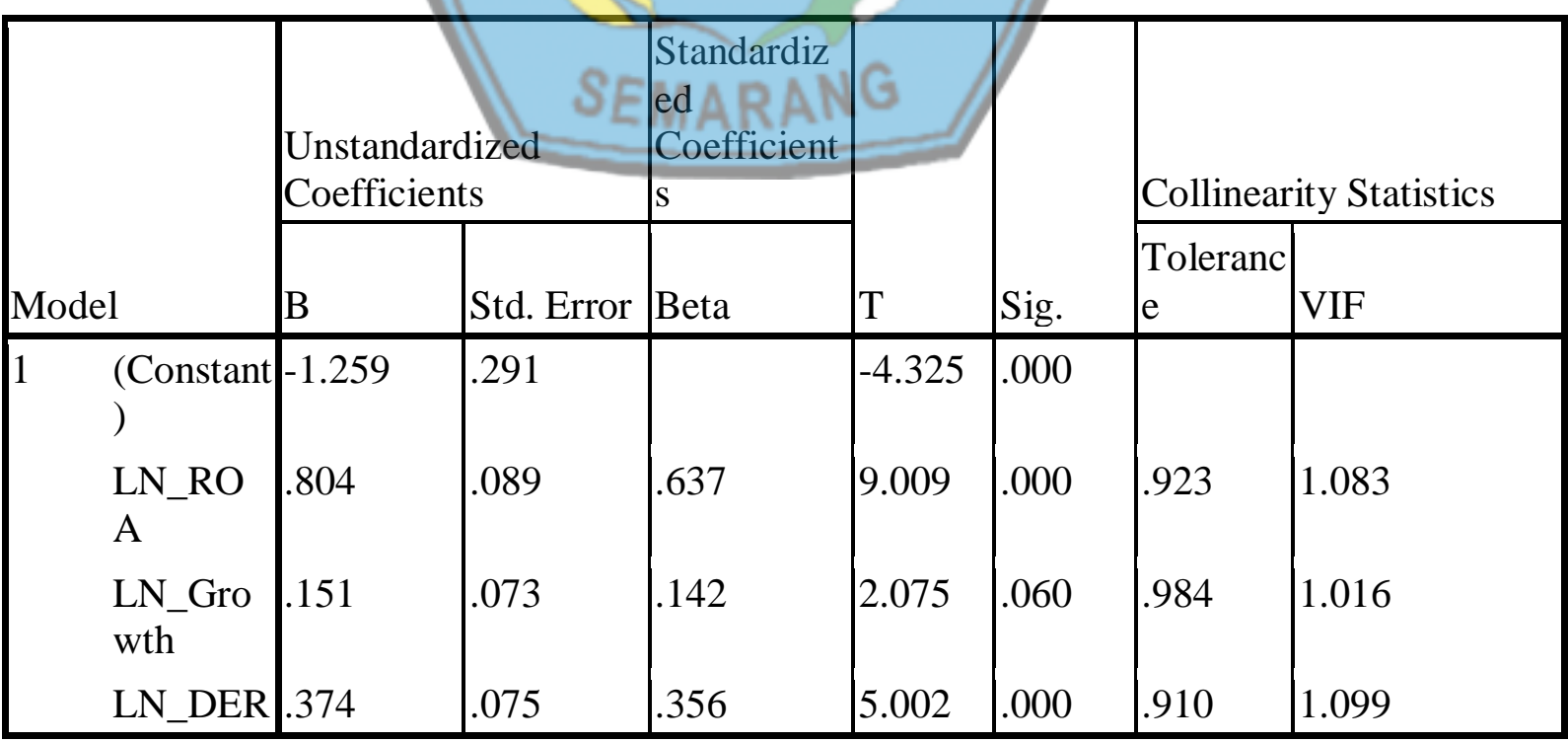

a. Dependent Variable: LN_PBV

\section{Uji Multikolinearitas}

Tidak terjadi multikolinearitas dalam model empiris yang diuji. Hal ini ditunjukkan dengan nilai tolerance dari LN_ROA sebesar 0.923 , nilai tolerance dari LN_growth sebesar 0.984 dan nilai

ANALISIS PENGARUH RASIO KEUANGAN.... 
tolerance dari LN_DER sebesar 0.910 . Berarti semua variabel independen memiliki nilai tolerance lebih dari 0.1. Hasil pertimbangan nilai VIF (Variance Inflation Factor) menunjukkan nilai VIF
LN_ROA sebesar 1.083, nilai VIF LN_Growth sebesar 1.016, dan nilai VIF LN_DER sebesar 1.099 yang berarti tidak ada satupun variabel independen yang memiliki VIF lebih dari 10

\section{Uji Heterokedastisitas}

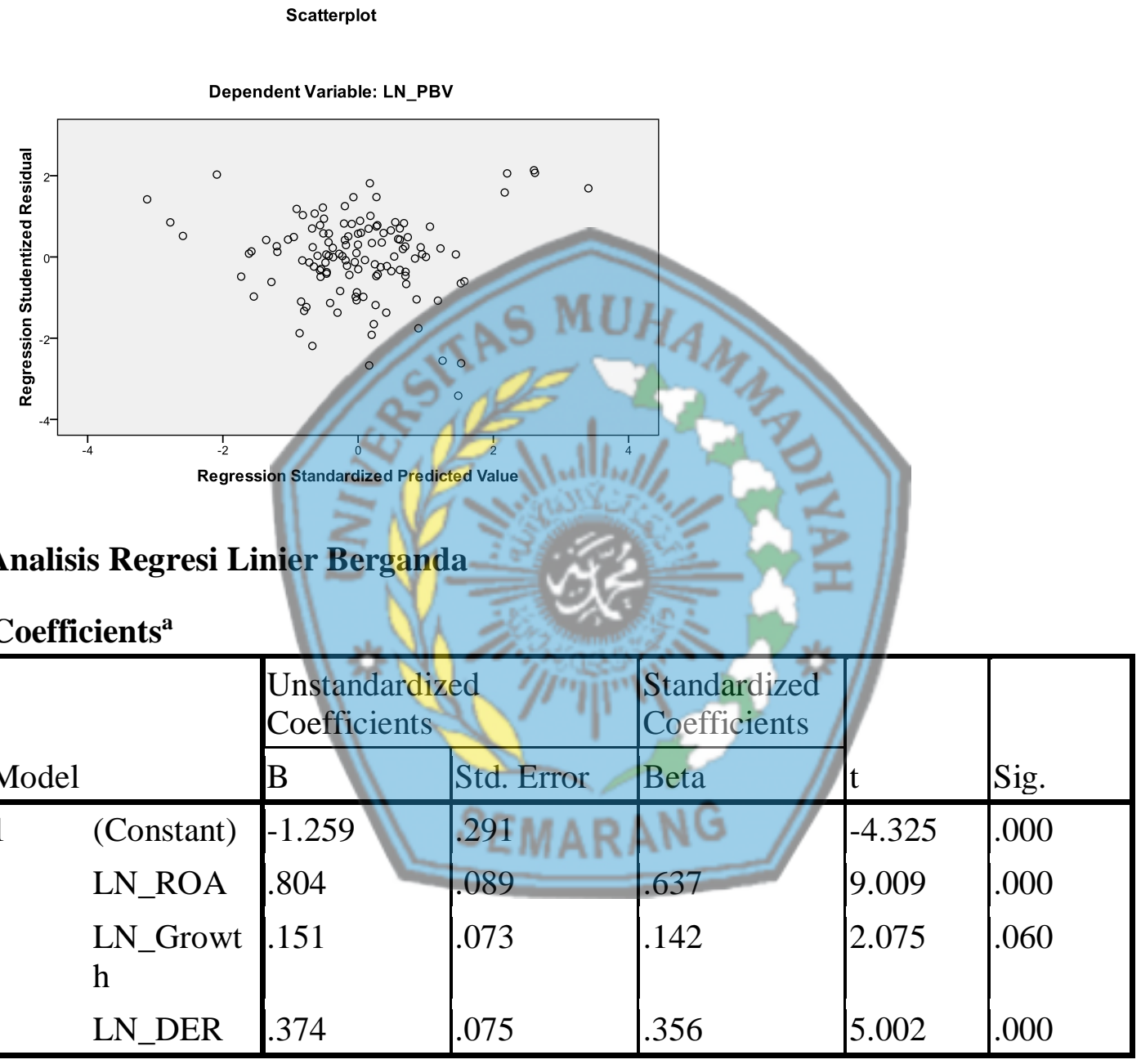

\section{a. Dependent Variable: LN_PBV}

Persamaan regresi yang terbentuk pada uji regresi ini adalah : $\mathrm{Y}=-1,259+0,804 \mathrm{X}_{1}+0,151 \mathrm{X}_{2}+$ $0,374 \mathrm{X}_{3}+\mathrm{e}$

Dari persamaan regresi di atas, dapat dijelaskan seperti di bawah ini :

a. Konstanta sebesar $-1,259$ menunjukkan bahwa apabila tidak ada variabel independen $\left(\mathrm{X}_{1}, \mathrm{X}_{2}\right.$, $\mathrm{X}_{3}=0$ ) maka nilai perusahaan sebesar $-1,259$. b. Nilai koefisien regresi untuk ROA $\left(\mathrm{X}_{1}\right)$ sebesar 0,804 menyatakan setiap peningkatan ROA sebesar $100 \%$ dengan asumsi variabel lainnya konstan maka akan meningkatkan nilai perusahaan (Y) sebesar $80,4 \%$

c. Nilai koefisien regresi untuk Growth $\left(\mathrm{X}_{2}\right) \quad$ sebesar $\quad 0,151$ menyatakan setiap peningkatan Growth sebesar 100\% dengan asumsi variabel lainnya konstan 
maka akan meningkatkan nilai perusahaan (Y) sebesar 15,1\%.

d. Nilai koefisien regresi untuk DER $\left(\mathrm{X}_{3}\right)$ sebesar 0,374 menyatakan setiap peningkatan DER sebesar $100 \%$ dengan asumsi variabel lainnya konstan maka akan meningkatkan nilai perusahaan (Y) sebesar 37,4\%.
Uji Parsial (Uji T)

Pengujian hipotesis secara parsial yaitu untuk mengetahui ada tidaknya pengaruh tiap-tiap variabel independen terhadap variabel dependennya yang dilakukan dengan uji t.

\section{Individual (Uji t $)$} Coefficients $^{\mathrm{a}}$

\section{Uji Hipotesis}

\begin{tabular}{|c|c|c|c|c|c|c|}
\hline \multirow{2}{*}{\multicolumn{2}{|c|}{ Model }} & \multicolumn{2}{|c|}{$\begin{array}{l}\text { Unstandardized } \\
\text { Coefficients }\end{array}$} & \multirow{2}{*}{\begin{tabular}{|l}
$\begin{array}{l}\text { Standardized } \\
\text { Coefficients }\end{array}$ \\
Beta \\
\end{tabular}} & \multirow[b]{2}{*}{$\mathrm{t}$} & \multirow[b]{2}{*}{ Sig. } \\
\hline & & B & Std. Error & & & \\
\hline \multirow[t]{4}{*}{1} & (Constant) & -1.259 & .291 & & -4.325 & .000 \\
\hline & LN_ROA & .804 & .089 & .637 & 9.009 & .000 \\
\hline & $\begin{array}{l}\text { LN_Growt } \\
\mathrm{h}\end{array}$ & .151 & & & 2.075 & .060 \\
\hline & LN_DER & .374 & .075 & 356 & 5.002 & .000 \\
\hline
\end{tabular}

b. Dependent Variable: LN_PBV

Hasil :

1. Pengaruh Profitabilitas (ROA) terhadap Nilai Perusahaan

Hasil pengujian menunjukar nilai variabel profitabilitas yang diukur dengan $\mathrm{ROA}^{*}\left(\mathrm{X}_{1}\right)$ sebesar 9,009 dengan signifikansi sebesar 0,00 atau $<0,05$ yang berarti bahwa model regresi tersebut signifikan.

2. Pengaruh Pertumbuhan Perusahaan terhadap Nilai Perusahaan

Hasil pengujian menunjukan variabel pertumbuhan perusahaan yang diukur dengan perubahan total aset atau growth $\left(\mathrm{X}_{2}\right)$ sebesar 2,075 dengan signifikansi sebesar 0,060 atau $<0,05$ yang berarti bahwa model regresi tersebut tidak signifikan.

3. Pengaruh Struktur Modal (DER) terhadap Nilai Perusahaan

Hasil pengujian menunjukan variabel struktur modal yang diukur dengan Debt to Equity Ratio $\left(\mathrm{X}_{3}\right)$ sebesar 5,002 dengan signifikansi sebesar 0,000 atau $<0,05$ yang berarti bahwa model regresi tersebut signifikan. Dengan demikian secara parsial struktur modal $\left(\mathrm{X}_{3}\right)$ berpengaruh positif dan signifikan terhadap nilai perusahaan (Y) atau dengan kata lain $\mathrm{H}_{3}$ yang menyatakan struktur modal berpengaruh positif dan signifikan terhadap nilai perusahaan diterima.

\section{KESIMPULAN}

1. Hasil perhitungan uji $\mathrm{t}$ untuk variabel profitabilitas yang diukur dari Return On Assets (ROA) diperoleh nilai sebesar 0,804 dengan signifikansi sebesar 0,000 atau < 0,05 yang berarti secara parsial variabel profitabilitas berpengaruh positif dan signifikan.

2. Hasil perhitungan uji $t$ untuk variabel pertumbuhan perusahaan yang diukur dari pertumbuhan aset perusahaan per tahun (growth) diperoleh nilai sebesar $0,151 \quad$ dengan signifikansi sebesar 0,060 yang menunjukan secara pasial variabel pertumbuhan 
perusahaan tidak signifikan terhadap nilai perusahaan.

3. Hasil perhitungan uji t untuk variabel Debt to Equity Ratio diperoleh nilai sebesar 5,002 dengan signifikansi sebesar 0,000 atau $<0,05$ yang berarti bahwa model regresi tersebut signifikan.

\section{Saran}

1. Bagi peneliti hendaknya dapat melakukan penelitian serupa dengan menambahkan variabel kepemilikan manajerial, kepemilikan institusional dan ukuran perusahaan yang diperkirakan dapat mempengaruhi nilai perusahaan sehingga didapatkan berbagai alternatif cara mengambil kebijakan dalam meningkatkan nilai perusahaan.

2. Diharapkan manajemen perusahaan dapat mengelola dan menggunakan aset perusahaan dengan efektif dan efisien sehingga dapat memaksimalkan laba dari hasil penjualan dan investasi perusahaan. Laba yang naik akan berimbas pada kenaikan Return On Assets yang semakin baik pula bagi nilai perusahaan dimata investor.

\section{DAFTAR PUSTAKA}

Agus Sartono. 2001. Manajemen $/ 4$ ke empat. Yogyakarta: Yayasan Keuangan Teori dan Aplikasi, Edisi ke empat. Yogyakarta: BPFE

Agnes. 2011. Pengaruh kepemilikan manajerial,struktur modal,dan ukuran perusahaan terhadap nilai perusahaan. Padang: Universitas Negeri Padang

Christianti, Ari. 2006. Penentuan Perilaku Kebijakan Struktur Modal Pada Perusahaan Manufaktur Di Bursa Efek Jakarta: Hipotesis Static Trade Off Atau Pecking Order Theory, Simposium Nasional Akuntansi IX.

Algifari. 2000. Analisis Regresi, Teori, Kasus \& Solusi. Yogyakarta: BPFE UGM.

Dewi, Ayu Sri Mahatma dan Wirajaya, Ary. 2013. Pengaruh Struktur Modal, Profitabilitas dan Ukuran

Arief, Sritua. 2006. Metodologi Penelitian Ekonomi. Jakarta: UI Press.

Augusty, Ferdinand. 2006. Metode Penelitian Manajemen. Semarang: Badan Penerbit Universitas Diponegoro

Ayuningtyas.Dwi. 2013. Pengaruh Profitabilitas Terhadap Nilai Perusahaan: Kebijakan Dividen dan Kesempatan Investasi Sebagai Variabel Antara. Jurnal STIESIA. Surabaya.
Perusahaan Pada Nilai Perusahaan. Jurnal. Volume 4.2 : 358-372

Ghozali, Imam, 2009. Aplikasi Analisis Multivariate Dengan Program SPSS, Edisi Keempat, Penerbit Universitas Diponegoro

Kaaro, Hermeindito. 2002. Searching Proxies of Investment Opportunity Sets and Identifying Information Content. Journal Manajemen dan Kewirausahaan. Vol 4 
Salvatore, Dominick. 2005. Ekonomi Manajerial dalam Perekonomian Global. Salemba Empat: Jakarta

Manufaktur Terbuka di Indonesia.. Disertasi tidak dipublikasikan. Universitas Airlangga. Surabaya.

Sulistiono. 2010. Pengaruh Kepemilikan Manajerial, Struktur Modal dan Ukuran Perusahaan terhadap Nilai Perusahaan pada Perusahaan Manufaktur di BEI tahun 20062008. Skripsi. Fakultas Ekonomi. Universitas Negeri Semarang.

Suranta, Eddy dan Pratana Puspita Merdistusi. 2004. Income Smoothing, Tobin's Q, Agency Problems dan Kinerja
Perusahaan. Simposium Nasional Akuntansi VII. Bali, $2-3$ Desember.

Taswan. 2003. Analisis Integrasi Strategis di LIK dan Dividen Terhadap Nilai Perusahaan serta Faktor-Faktor yang Mempengaruhinya. Jurnal Bisnis dan Ekonomi.

Ulupui, I.G.K.A. 2007. Analisis Pengaruh Rasio Likuiditas, Leverage, Aktivitas dan Profitabilitas terhadap Return Saham (Studi pada Perusahaan Makanan dan Minuman dengan Kategori Industri Barang Konsumsi di BEJ). Jurnal Ekonomi. Universitas Udayana. 